\title{
Bioenergy Technology Solutions in Brazil
}

\author{
Clara Lisseth Mendoza Martinez ${ }^{1}$, Márcia Silva de Jesus ${ }^{2 \star}$, Esa Vakkilainen², Marcelo \\ Cardoso $^{1}$, Gustavo Matheus Almeida ${ }^{1}$ \\ ${ }^{1}$ Departamento de Engenharia Química, Universidade Federal de Minas Gerais, Belo Horizonte, MG, Brasil. \\ ${ }^{2}$ Departamento de Engenharia Florestal, Universidade Federal de Viçosa, Viçosa, MG, Brasil. \\ ${ }^{3}$ Lappeenranta University of Technology, Finlândia.
}

\begin{abstract}
Governments and society are concerned about the climate change that has been increasing over the years. It is known that the main cause is the emission of greenhouse gases, due to the burning of non-renewable fuels that are mainly used in the generation of energy both in companies and in the transport industry. At this moment a great opportunity opens up for the diffusion and the stimulus of the use of renewable energies, in order to make the energy matrix more sustainable. This article presents an overview of the Brazilian energy matrix, background, challenges and degree of sustainability in the production of energy, based on economic and environmental aspects of its production. Due to hydroelectricity and bioethanol, Brazil is still in a privileged position compared to many other countries in the South American. The country is self-sufficient in oil and complements its generation of energy with "modern" resources, i.e. wind, solar and biomass plants. However, future will largely depend on how the government will be able to shape its renewable energy policies as the country faces challenges regarding regulations for innovation and foreign investment.
\end{abstract}

Keywords: Energy matrix; renewable source; megatrends.

\section{Soluções Tecnológicas em Bioenergia no Brasil}

RESUMO Nos últimos anos, a sociedade e as autoridades públicas têm demonstrado maior interesse sobre as mudanças climáticas, as quais são mais significativas ao longo dos anos. Sabe-se que o principal fator de agravamento desse processo é a emissão de gases de efeito estufa, em razão da queima de combustíveis não renováveis, utilizados principalmente por empresas e pelo setor de transportes para a geração de energia. Neste momento, tem-se uma grande oportunidade para a difusão e o estímulo ao uso de energias renováveis, com o objetivo de uma matriz energética mais sustentável. Este artigo apresenta uma visão geral da matriz energética brasileira, e o histórico, os problemas e as questões sobre a sustentabilidade do setor energético no país, com base em aspectos econômicos, sociais e ambientais. Em razão do potencial hidroelétrico e da presença do bioetanol na matriz energética brasileira, o país está em posição privilegiada em relação a maioria dos países da América do Sul. O país é autossuficiente em petróleo e complementa sua geração de energia com recursos "modernos", tais quais, usinas eólica, solar e de biomassa. No entanto, o futuro depende, em grande parte, de como o governo conduzirá as políticas de energia renovável, uma vez que o país enfrenta desafios relativos às regulamentações sobre inovação e investimento estrangeiro.

Palavras-chave: Matriz energética; energia renovável; megatendências.

\section{Introduction}

Brazil is going through considerable transformations in the political, social, environmental and economic fields. Several key trends act together and influence the development stages and living standards of societies. Successful countries will be those that adapt to these trends and discover how to turn them into opportunities. Energy consumption is one of the main indicators of the country performance. Brazil is facing this energy challenge with two strategies: (i) maintaining the renewable energy matrix, and (ii) promoting energy efficiency and energy conservation through various

* Corresponding author: eng-marcia@hotmail.com 
government programs (OLIVEIRA; TRINDADE, 2018). The government opted to use its state-owned companies Eletrobras and Petrobras - to execute the energy programs in a collaborative action between Ministry of Mines and Energy - Ministério de Minas e Energia (MME), National Agency of Electrical Energy - Agência Nacional de Energia Elétrica (ANEEL), National Petroleum, Natural Gas and Biofuels Agency - Agência Nacional do Petróleo, Gás Natural e Biocombustiveis (ANP), National Institute of Metrology, Normalization and Industrial Quality - Instituto Nacional de Metrologia, Normalização e Qualidade Industrial (INMETRO). All programs are conducted by the National Council of Energy Policy - Conselho Nacional de Política Energética (CNPE) - through a National Program on Energy Efficiency - Plano Nacional de Eficiência Energética (MME).

In 2017, the largest share of the Brazilian energy came from petroleum and oil products (36\%), followed by sugarcane by-products use (17\%), hydroelectricity (12\%), and natural gas (13\%) (EPE, 2018). At the same time, the electricity generation mix was predominantly renewable, with domestic hydroelectricity production accounts for $68 \%$ of the supply (EPE, 2018). Hydropower presented a relatively advantageous source of renewable electricity; and with one of the largest hydroelectric potentials in the world, Brazil will continue to expand the hydroelectric generation (SILVA et al., 2016). However, the country's strong dependency on a single energy source threatens the security of electricity supply considering the predicted growth of the power demand in the near future. Within the present expansion rates, Brazil will reach the maximum obtainable capacity of hydroelectric generation in the next decades (SILVA et al., 2016; BRADSHAW, 2017). In addition, the vulnerability of the systems is increased in case of the droughts, which were already experienced in the last years (SILVA, 2016). Under these circumstances, the country energy supply system has to be modified to be more balanced within other renewable sources. Figure 1 shows the structure of the internal supply of electricity in Brazil according to the national energy balance in 2018 - base year 2017 (EPE, 2018) and the energetic projection for 2030 (TOLMASQUIM et al., 2007).
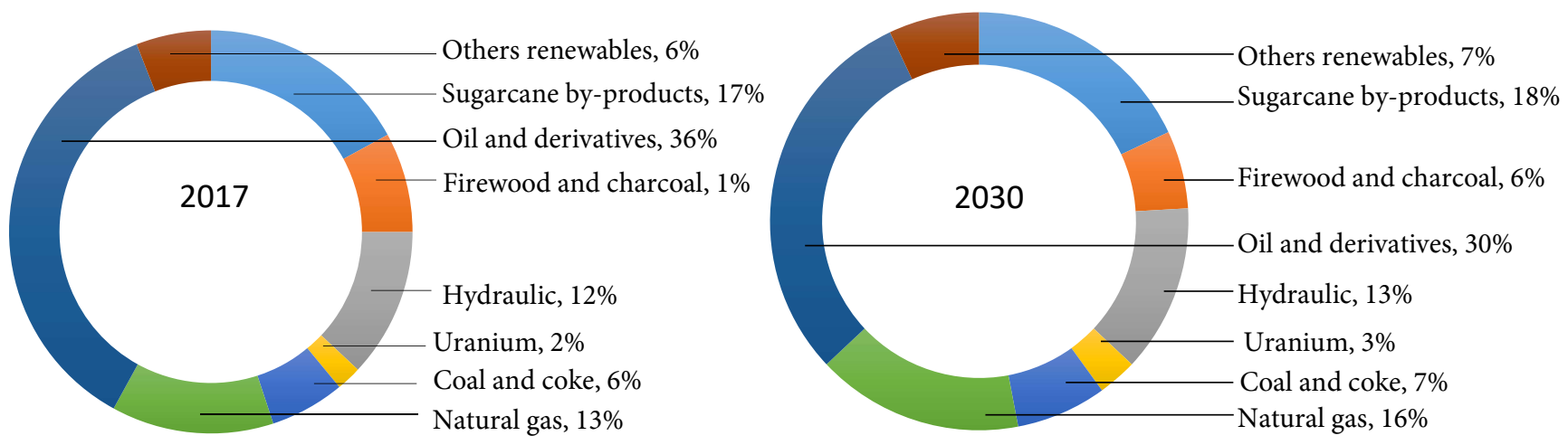

Figure 1. Domestic electricity supply by source in 2017 and 2030.

Figura 1. Fornecimento de energia elétrica por fonte em 2017 e 2030.

The Figure 1 shows that the participation of nonrenewable sources will be important in 2030 and the application of renewables will still continue growing. The energy policies implemented in Brazil are mainly aimed on 
supporting the use and production of liquid biofuels (FELFLI et al., 2011). At the same time, use of residual biomass for energy generation is not promoted in the sufficient way. According to the Brazilian energy balance (2017), the share of bioenergy (incl. sugarcane, forest residues and black liquor from pulp and paper industry) in the domestic power supply was about $9 \%$ in 2016 with $14 \mathrm{GW}$ of installed capacity (almost $80 \%$ is by sugarcane bagasse utilization facilities). Recent incentives (Brazil's 'National Climate Change Plan', '2030 National Energy Plan' and 'Decennial Plan') determine certain targets for the reduction of the greenhouse gas emissions and increasing renewable energy generation - with particular focus on bioenergy and hydropower in large scale. Brazil has a significant bioenergy potential that can be successfully used for both, the domestic energy demand and the exports targets (WELFLE, 2017).

The production of electricity in Brazil has a variety of technologies that use fuels, wind energy, agricultural waste, biogas, solar energy, among others. Studies show a high participation of fossil fuel power plants in the energy matrix, as can be seen in the current energy balances, where the national oil production grew 3\% in 2016 (LIMA et al., 2015). The main reason was the strong growth of production in the Lula and the Sapinhoá oil fields (EPE, 2018). However, Brazilian energy policies prioritize the use of domestic liquid biofuels to increase energy production. At the same time, recurring international concerns about the need to promote the development of nations by improving the quality levels of life, education, culture and health request alternative solutions against the usual limited funds.

In this direction, the increased implementation of renewable energies can be a vector to induce further sustainable development in Brazil. In particular, the continued implementation of energy crops and challenges related to the possible impacts that can be caused by the country's current energy consumption patterns (LORA; ANDRADE, 2009). It will also highlight the importance of hydroelectricity and bioethanol, which put Brazil in an important position in relation to the other countries around the world. The replacement of gasoline by ethanol, diesel by biodiesel and fuel oil by sugarcane bagasse, are important to reduce the external dependence on oil, which is the reality of Brazil and of many other South American countries.

The objective of this work is to show an overview of the Brazilian energy matrix, background, challenges and degree of sustainability in the production of energy, based on economic and environmental aspects, in order to analyze the bioenergy technologies as a solution to expand the Brazilian energy matrix. Trends that affect the Brazilian energy sector was also included, as well as an assessment of the main ongoing projects.

\section{Megatrends that affect Brazil in the energy}

\section{sector}

The demographic growth rate (Fig. 2) of the population in majority of the countries has contributed significantly to changes in all social areas, from the economic to political and environmental power (DEAN et al., 2015; EEA, 2015). Some of the societies face declining growth, which affects their respective work forces in relation to population. On the other hand, societies that keep a constant growth rate benefits from more standardized work forces and markets, results in greater growth prospects (SAMANS et al., 2017). These societies have the challenge of feeding, educating and employing their new members in order to achieve high productive potential.

According to reports from the United Nations (UN, 2014), Brazil is the fifth largest country in terms of population in the world, after China, India, United States and Indonesia. Its population represents approximately $2.76 \%$ of the world population, and it has been gradually increasing. The last 
demographic censuses showed an increment of approximately $0.75 \%$ from 2017 to 2018, which is considerable high when compared to China (0.39\%), that presents the largest population of the world (18.58\%) (WORLSDOMETERS, 2018).

With the growth of the population, the demand of energy also gradually increases, since it is necessary for industrial, agricultural and transport developments. The population, that is, families or individuals, consume energy through the market or domestic production. According to the Brazilian energy balance (EPE, 2018), in 2016, the highest energy consumption was found in the service sector (39.5\%), more specifically in trade and transport, followed by the industrial sector $(35 \%)$. The greater contributions to the industrial transformation is granted to the ferrous and non-ferrous plants, foods and beverages companies, and paper and pulp mills (EPE, 2018).

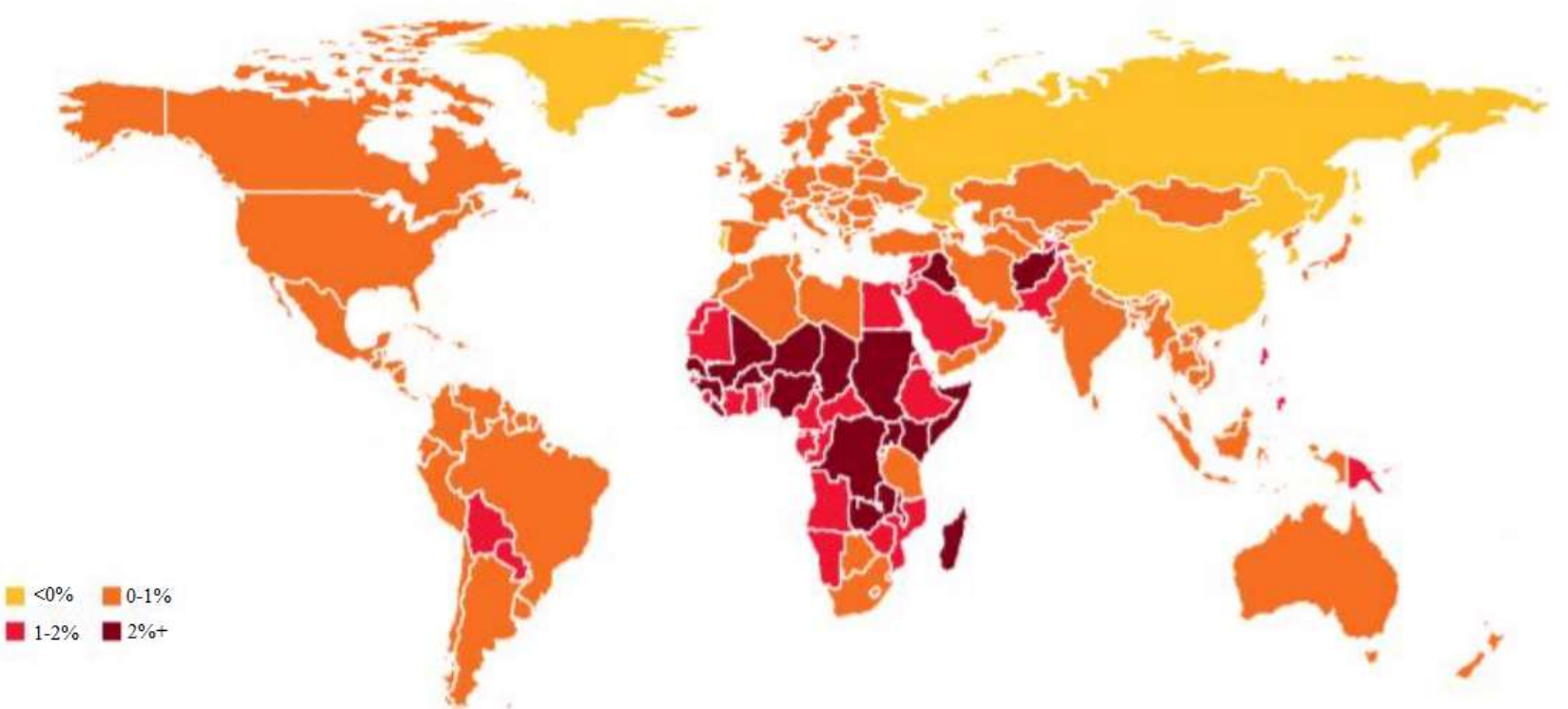

Figure 2. Annual population growth rate, 2010 - 2050 (MODLY, 2016)

Figure 2. Taxa de crescimento anual da população, 2010 - 2050 (MODLY, 2016)

The domestic production directly generates environmental impacts at the end of consumption, whereas goods and services obtained through the market represent indirect or external impacts due to the use of materials and energy during production, transport and marketing (SAWYER, 2015). In addition, the education, health and transportation facilities, who are major consumers of the energy production chain must be taken into account for the sustainable development analysis of a country.

Besides the development of the markets, it is important to recognize the commercial networks and the investments among them. Innovation plays a very important role in the growth and structural change of the economy. Brazil faces the transition from the agrarian economy to industrialization. Increasing the productivity of developing regions such as the Amazon and of already emerging regions such as Minas Gerais (EEA, 2015). One of the possible implications of the change of economic power is the increasingly multipolar world, due to the change of the competitive environment of the companies due to variations in the organizations led (MODLY 2016). This type of economy opens space for new global references of sectoral businesses that in a certain way 
can create and support regions that want to develop. However, established and mature markets may lose influence and cease to be attractive for the business (BONASSA et al., 2018).

Brazil makes part of the group of countries known as BRICS (Brazil, Russia, India, China and South Africa). This group is composed of emerging countries, which in the next 50 years could become the main strength of the global economy, becoming even greater than the current G7 (Canada, France, Germany, Italy, Japan, United Kingdom and United States) (VIEIR; VERÍSSIMO 2009). These nations have in common a dense population and a large territory, which gives them a strategic continental dimension and availability of natural resources. These factors attract a lot of foreign direct investment, low labor costs and high Gross Domestic Product (GDP) growth rates. In this context, Brazil is the most prosperous market in Latin America, with innumerable projects regarding industrialization, urbanization, technological innovations and international cooperation, which improves the level of education and employment opportunities, environment and climate changes (AL-MULALI et al., 2016).

Koengkan et al. (2017) studied the impact of wind energy production on the market. They demonstrated that renewable energy public policies not only results in clean energy also generating jobs and economic development in some particular regions. On the other hand, Del Rio and Burguillo (2008), concluded that renewable energy projects have positive effects on the municipal budget since these projects involve granting of subsidies for companies and local communities with government funds, in addition to financial transfers for environmental compensation.

The scarcity of resources and the impact of climate changes are a growing economic concern as well. Energy demand is expected to increase by more than $50 \%$ by 2030 and water withdrawals by $40 \%$ (ANDRADE et al., 2015). The need for sustainable solutions may be in conflict with the need of resources to boost growth and feed populations. The most consecrated traditions will be challenged by changes in the physical environment (VIEIRA; VERÍSSIMO, 2009; MARGULIS; SCHMIDT, 2010).

The impact of the climate variations because of the increasing global temperatures could reduce the country GDP and slight increase poverty. The region most vulnerable to this physical phenomenon in Brazil will be the Amazon and the Northeast, with a reduction of approximately $40 \%$ in floral coverage (VIOLA; FRANCHINI, 2017). In the rest of the country, expressive losses in agriculture will be evident, with the exception of cooler regions in the south and southeast that will keep more pleasant temperatures (MARGULIS; SCHMIDT, 2010). However, the country is preparing with some mitigation actions, for example, the replacement of fossil fuels, which will avoid domestic emissions of 92 to 203 million tons of CO2 equivalent until 2035 (LIMA, 2017). The growth of planted areas would avoid both the substitution of areas originally destined to subsistence cultures and the deforestation of the Amazonian region (MARGULIS; SCHMIDT, 2010).

The Brazilian National Policy on Climate Change goal, is to reduce emissions between $36.1 \%$ to $38.9 \%$ by 2020 . In addition, considering the size of its territory, the country contribution to global greenhouse gases emissions (GHG) is relatively small, $3.4 \%$ of the world total (SEEG, 2016). In that sense, the use of renewable energies has a great implication in the country energy policies. The estimated potential for reducing emissions would be 1.8 billion tons of $\mathrm{CO} 2$ in the 2010-2030 period. With a discount tax of $8 \%$ per year, the estimated cost would be negative meaning a benefit of US\$ 34 billion until 2030, which is equivalent to US\$ 13 per ton of CO2 (MARGULIS; SCHMIDT, 2010). 


\section{Technology solutions}

A wide range of technologies are available now and in constant development for optimization with the aim of satisfying the global energy demand. The energy scenario is mainly focused on energy savings and renewable sources potential, primarily in the heat and power generation sectors (GREENPEACE et al., 2015). The technologies implemented for the generation of energy depend mainly on the type of fuel that is being used.

Oil, coal and natural gas combustion are the main fossil fuel technologies, commonly used for power generation. Oil is still used in areas where other fuels are not readily available, such as islands or remote sites. In that sense, technologies have been introduced to improve the environmental performance of conventional fossil fuel combustion (GREENPEACE et al., 2015). These include fuel cleaning technologies, to reduce emissions of particulates, Sulphur dioxide (SO2) and nitrogen oxide (NO) and combined cycle gas turbine (CCGT), where the gas turbine generator produced electricity and the exhaust gases from the turbine are used to make steam to generate additional electricity (RODRIGUES et al., 2003; GREENPEACE et al., 2015). Several studies about the implementation of new technologies and the main issues and uncertainties affecting electricity demand and supply in Brazil have been carried out, Rodrigues et al. (2003) evaluate the co-firing of gas derived from biomass and natural gas combined system to increase the energetic efficiency and Gomes et al. (2013) analyzed the use of the Brazilian coal and biomass through a cleaner production in order to reduce atmospheric emissions and ashes.

The use of renewable power and heating technologies are atractive solutions for the Brazilian energy matrix expansion. Renewable energy includes sources such as biomass, solar energy, geothermal heat, hydropower, ocean thermal and wind energy. Currently, the country has a large contribution from renewable sources, approximately $42 \%$ of the Brazilian total primary energy supply come from renewables (EPE, 2018). The decennial plane of Brazilian energy expansion 2024, offers a promising perspective for the energy industry in Brazil, based on an integrated view of the various energy sources, providing a market with better investment decisions (EPE, 2015). Photovoltaic, wind energy and biomass technologies are currently being improved the most in the country.

Photovoltaic (PV) technology involves the generation of electricity of light. According to Greenpeace et al. (2015), each square meter of land is exposed to enough sunlight to produce $1,700 \mathrm{kWh}$ of power every year. European countries have been developed specific regulatory mechanisms to encourage the PV systems either by government programs or by financial and tax incentives. In Brazil, the encouragement to technology is still incipient, despite the large existing solar potential (FERREIRA et al., 2018). However, the International Renewable Energy Agency revealed that Brazil had installed 1GW of solar generation in 2017 and several projects are in progress (BARROS, 2018).

Wind energy has grown faster than all other electricity sources in the last 20 years worldwide (GREENPEACE et al., 2015), in Brazil over the last decade the wind energy increased from $19 \hat{\mathrm{A}} \mathrm{MW}$ to $2.2 \hat{\mathrm{A}} \mathrm{GW}$ (PES et al., 2017). Nowadays, modern wind technology is available for low and high wind speeds, and in a variety of climates (GREENPEACE et al., 2015). Brazil implemented industrial policies in the wind energy sector in some regions of the country, motivated by national programs to stimulate the development of this source (ADAMI et al., 2017). According to Jong et al. (2017), wind powerin the Brazilian Northeast (NE) is expected to generate $57 \%$ of the NE electricity supply by 2020 . 
Programs, projects and technologies related to the use of biofuels in Brazil have an important participation in the energy matrix, the availability of biomass and electricity generation potential for different industrial and agricultural sector is increasing. Several studies have been carried out, Martinez et al. (2019) present selected agroindustry solid residues from Brazilian coffee production chain for energy purposes, Walter et al. (2011) and Bordonal et al. (2018) reported the high efficiency of sugar cane for ethanol production.

\section{Challenges and opportunities to increase}

\section{biomass usage in Brazil}

Handling solid biomass (branches, animal carcasses, leaves, barks, among others) is not economical feasible for the purpose of generating energy. The concentration of energy is low and there is no regularity of physical properties such as dimension, density, humidity, stiffness, which are crucial factors for transportation, handling and storage (LUBWAMA; YIGA, 2018). One of the solutions found is the conversion of biomass into liquid and gaseous biofuels with higher energy density and more viable characteristics. There are several processes of biomass conversion to produce heat, electricity and/or fuels. They can be grouped into three categories, namely physical-chemical, biochemical and thermochemical, as presented below.

- Physical-chemical: They involve physical transformations in the biomass that do not result in molecular modifications. Among the most common operations are: (i) densification, (ii) granulometric reduction, and (iii) mechanical pressing (TURKENBURG et al., 2000).

- Biochemical: Biomass molecules are broken down into smaller molecules by the action of living organisms, namely bacteria or enzymes. The three main conversion routes are (i) digestion, (ii) fermentation, and (iii) hydrolysis (BASU, 2013).

- Thermo-chemical: All the biomass is either directly burned or converted into gases that are used to synthesize biofuel for power generation. Among the conversion options are the routes of (i) combustion, (ii) pyrolysis, (iii) gasification, and (iv) liquefaction (BASU, 2013).

Traditionally, the main technologies for thermochemical conversion of biomass studied in Brazil are: combustion, pyrolysis, torrefaction and gasification. In each one, a series of reactions occurs with the hydrocarbons, cellulose, hemicelluloses and lignin, compounds generally present in the biomass (YANG et al., 2007). Modern biomass is used in several sectors of the economy in Brazil. The industrial sector have the pulp and paper mills that uses wood and bleach residues as fuel in gasification processes (JOELSSON; GUSTAVSSON, 2008); the cogeneration systems with sugarcane bagasse in the sugar and alcohol sector and in the beverage sector, especially in the fruit juice processing industries; and also the sawmills that use wood residues in the production of heat for plant operations and electricity generation (JUNIOR, 2004).

The implementation of a program for the production and use of ethanol from sugarcane would certainly not have to go through all the steps that Brazil has already successfully overcome. By replicating this initiative, it is possible to take a technological leap and produce ethanol at competitive prices. Another important point concerns the reforestation policy of the Brazilian paper and pulp industry. This sector, that is frequently breaking records, produces 10.357 million metric tons of paper per year (FARINHA et al., 2016). For instance, a factory in the state of Mato Grosso do Sul, known to be the largest single-line factory in the world, uses eucalyptus plantations to obtain kraft pulp for paper raw material. Três Lagoas is another example of a mega factory in Brazil that 
often break its own world records regarding daily pulp production.

The pulp and paper industry is energy intensive, with significant amounts of carbon dioxide $\left(\mathrm{CO}_{2}\right)$ emissions. The sector is making increasing efforts to reduce fossil fuel use, and consequently emission levels in all parts of the world (FRACARO et al., 2012). A large share of energy use in the pulp industry is already based on biomass (IEA, 2017). Under normal operations, modern kraft pulp mills are generally selfsufficient in energy making the carbon neutral if the biomass used by the industry is cultivated and harvested in a sustainable way. If the $\mathrm{CO}_{2}$ emissions from the pulp and paper industry are captured and stored permanently, this can make the pulp industry a potential carbon sink.

To increase the use of biomass and to develop the technology needed for this, different aspects must be taken into account: (i) Investments in agricultural and industrial development, (ii) Training of human resources, (iii) Adequate legislation (environmental protection, transportation sector (regulation, fuel quality, percentage of biofuel, inspection) and electrical sector (authorization for the production and sale of bioelectricity, market rules), and (iv) Infra-structure for the production, distribution and exportation.

Among the environmental aspects, the challenges for the production of biofuels in Brazil from biomass concern the reduction of greenhouse gases, since it is necessary to assess the life cycle of the region and the development of a standardized accounting methodology (BLOTTNITZ; CURRAN, 2007). On the other hand, poor planning may cause soil erosion, water pollution, evaporative air emissions and possible loss of biodiversity (DEMIRBAS, 2009). However, the opportunity to overcome these barriers can maximize synergy in many areas at the national level.
With respect to economic aspects, the challenges are: the scale of production; the availability of the energy market as well as the obtaining of raw material; the local and international subsidies of the raw material; the high material costs, conversion and transportation; the availability of financing internal and external and the import rates (DEMIRBAS, 2009). The thrill of these barriers creates the opportunities for an economic and national market uplift and the identification of viable businesses.

Finally, regarding social aspects, the challenges for the production of energy are the distribution of benefits, existing monopolies, food security and resistance to changes. However, overcoming these challenges generates the opportunity to increase the commitment of the public administration and also creates strategies for poverty reduction (GUI; MACGILL, 2018).

\section{Final Considerations}

Brazil has the largest renewable energy market in Latin America and half of its energy is generated by natural inputs (78\%); this is more than three times the world average. The diversity of energy sources (hydroelectric, wind, biomass, solar) is the key issue of the Brazilian energy matrix relevance, once in addition to a mixture of alternatives, it also contributes to the dilution of geopolitical risks. According to the Brazilian Ministry of the Environment, the country, despite having a renewable energy matrix, it still needs new investments to improve the energy production chain to make it sustainable, to encourage research and to develop new technologies.

On the other hand, the main obstacle the country is facing in the energy sector is precisely the absence of public policies that would ensure the establishment of public actions to encourage the development of the energy industry. Although Brazil is considered a world leader in renewable energy, which 
guarantees the credibility to negotiate international proposals, agreements and protocols, linked to the following topics: greenhouse gas reduction, climate change and low carbon production. These are the main issues addressed today, related to economic, social and environmental sustainability.

\section{References}

ADAMI, V. S.; JÚNIOR, J. A. V. A.; SELliTTO, M. A. Regional industrial policy in the wind energy sector: The case of the State of Rio Grande do Sul, Brazil. Energy Policy, v.1, n.111, p. 18-27, 2017.

AL-MULALI, U.; SOLARIN, S. A.; OZTURK, I. Biofuel energy consumption-economic growth relationship: an empirical investigation of Brazil. Biofuels, Bioproducts and Biorefining, v.10, n.6, p. 753-775, 2016.

ANDRADE, J. B. S. O.; DUTRA, L.; SCHWINDEN, N. B. C.; ANDRADE, S. F. Future scenarios and trends in energy generation in Brazil: supply and demand and mitigation forecasts. Journal of Cleaner Production, 103, 197-210, 201. BARROS, R. 2018. "Centralized Solar Photovoltaic Generation in Brazil.” Associaçao Brasileira de Energia Solar Fotovoltaica-ABSOLAR. 2018 (in Portuguese).

BASU, P. Biomass gasification, pyrolysis and torrefaction: practical design and theory. Canada: Academic press, 2018.

BLOTTNITZ, H.V.; CURRAN, M. A. A review of assessments conducted on bio-ethanol as a transportation fuel from a net energy, greenhouse gas, and environmental life cycle perspective. Journal of cleaner production, v.15, n.7, p.607-619, 2007.

BONASSA, G.; SCHNEIDER, L. T.; CANEVER, V. B.; CREMONEZ, P. A.; FRIGO, E. P.; DIETER, J.; TELEKEN, J. G. (2017). Scenarios and prospects of solid biofuel use in Brazil. Renewable and Sustainable Energy Reviews, v.82, n.3, p.2365-2378, 2017.

BORDONAL, R.O.; CARVALHO, J. L. N.; LAL, R.; FIGUEIREDO, E. B.; OLIVEIRA, B. G.; LA SCALA, N. Sustainability of sugarcane production in Brazil. A review. Agronomy for sustainable development, v.38, n.2, p.13, 2018.

BRADSHAW, A. Regulatory change and innovation in Latin
America: The case of renewable energy in Brazil. Utilities Policy, v.1, n.49, p.156-164, 2017.

SILVA, R. C.; MARCHI NETO, I.; SEIFERT, S. S. Electricity supply security and the future role of renewable energy sources in Brazil. Renewable and Sustainable Energy Reviews, v.1, n.59, p.328-341, 2016.

DEAN, A., PETERSON, D. 2015. Embracing Global Megatrends. National Association of corporate Directors NACD. January/February 2015.

DEMIRBAS, A. Political, economic and environmental impacts of biofuels: A review. Applied energy, v.86, p. S108S117, 2009.

EEA. Assessment of Global Megatrends - an Update. European Environment Agency. 2015.

EPE. Brazilian Energy Balance 2018 - Year 2017. Empresa de Pesquisa Energética, Rio de Janeiro, 2018.

EPE. Plano Decenal de Expansão de Energia 2024. Empresa de Pesquisa Energética, Rio de Janeiro, 2015.

GOMES, G. M. F.; VILELA, A. C. F.; DALLA ZEN, L.; OSÓRIO, E. Aspects for a cleaner production approach for coal and biomass use as a decentralized energy source in southern Brazil. Journal of cleaner production, v.47, p.8595, 2013.

FARINHA, C.A., MENDES, J., RODRIGUES, M.; 2016. The Pulp and Paper Industry in Brazil. Associaçao Brasileira Técnica de Celulose e Papel - ABTCP. Guia ABTCP fornecedores \& fabricantes celulose e papel 201572016.

FELFLI, F. F., ROCHA, J. D., FILIPPETTO, D., LUENGO, C. A., \& PIPPO, W. A. Biomass briquetting and its perspectives in Brazil. Biomass and bioenergy, v.35, n.1, p.236-242, 2011.

FERREIRA, A.; KUNH, S. S.; FAGNANI, K. C.; SOUZA, T. A.; TONEZER, C.; SANTOS, G. R.; COIMBRA-ARAÚJO, C. H. Economic overview of the use and production of photovoltaic solar energy in Brazil. Renewable and Sustainable Energy Reviews, v.81, p.181-191, 2018.

FRACARO, G., VAKKILAINEN, E., HAMAGUCHI, M., \& MELEGARI DE SOUZA, S. N. Energy efficiency in the Brazilian pulp and paper industry. Energies, n.5, v.9, p.35503572, 2012.

GREENPEACE, GWEC, SPE. Energy [R]Evolution: A 
Sustainable World Energy Outlook 2015. Report $5^{\text {th }}$ edition 2015 world energy scenario. London: Outlook, 2015.

GUI, E. M.; MACGILL, I. Typology of future clean energy communities: an exploratory structure, opportunities, and challenges. Energy Research \& Social Science, v.35, p,94$107,2018$.

IEA. World Energy Outlook - 2017. International Energy Agency. 2017

JOELSSON, J. M.; GUSTAVSSON, L. CO2 emission and oil use reduction through black liquor gasification and energy efficiency in pulp and paper industry. Resources, Conservation and Recycling, v.52, n.5, p.747-763, 2008.

JONG, P.; DARGAVILLE, R.; SILVER, J.; UTEMBE, S.; KIPERSTOK, A.; TORRES, E. A. Forecasting high proportions of wind energy supplying the Brazilian Northeast electricity grid. Applied energy, v.195, p. 538-555, 2017.

JONG, P.; DARGAVILLE, R.; SILVER, J.; UTEMBE, S.; KIPERSTOK, A.; TORRES, E. A. Forecasting high proportions of wind energy supplying the Brazilian Northeast electricity grid. Applied energy, v.195, p. 538-555, 2017.

JUNIOR, A.V. 2004. “Aproveitamento Dos Resíduos de Serraria Na Geração de Energia Elétrica No Município de Ulianópolis, Estado Do Pará: Estudo de Caso Incentivo à Exploração." Centro Nacional de Referência em Biomassa, São Paulo: 2004.

KOENGKAN, M., FUINHAS, J. A., \& MARQUES, A. C. O impacto da produção de energia eólica no mercado de trabalho: Uma abordagem pvar. Revista de Estudos Sociais, v.19, n.38, 36-49, 2017.

LIMA, F., PORTUGAL-PEREIRA, J., LUCENA, A. F., ROCHEDO, P., CUNHA, J., LOPES NUNES, M., \& SZKLO, A. S. Analysis of energy security and sustainability in future low carbon scenarios for Brazil. Natural Resources Forum, v.39, n.3-4, p.175-190, 2015.

LIMA, R. C. Futuro da inserção internacional do Brasil: questões para o desenvolvimento até 2035. Repositório Do Conhecimento: Instituto de Pesquisa Econômica Aplicada, 2017.

LORA, E. S.; ANDRADE, R. V. Biomass as energy source in Brazil. Renewable and Sustainable Energy Reviews, v.13, n.4, p.777-788, 2009.
LUBWAMA, M.; YIGA, V. A. Characteristics of briquettes developed from rice and coffee husks for domestic cooking applications in Uganda. Renewable energy, v.118, p.43-55, 2018.

MARGULIS, S.; DUBEUX, C. Economia da mudança do clima no Brasil. Boletim regional, urbano e ambiental, 2011.

MARTINEZ, C.L.M; ROCHA, E.P.A.; CARNEIRO, A.C.O.; GOMES, F.J.A.; BATALHA, L.A.R.; VAKKILAINEN, E.; CARDOSO, M. "Characterization of residual biomasses from the coffee production chain and assessment the potential for energy purposes." Biomass and Bioenergy, v.120, p.68-76, 2019.

MODLY, T. Five Megatrends And Their Implications for Global Defense \& Security. PriceWaterhouseCoopers - PwC. Canada, 2016.

OliveirA, J. F. G.; TRINDADE, T. C. G. Case Study: Evaluation of Renewable Energy Production Technologies in Two Regions of Brazil. Sustainability Performance Evaluation of Renewable Energy Sources: The Case of Brazil, p.89-116, 2018.

PES, M. P.; PEREIRA, E. B.; MARENGO, J. A.; MARTINS, F. R.; HEINEMANN, D.; SCHMIDT, M. Climate trends on the extreme winds in Brazil. Renewable Energy,v.109, p.110-120, 2017.

RÍO, P.D.; BURGUILlO, M. Assessing the impact of renewable energy deployment on local sustainability: Towards a theoretical framework. Renewable and sustainable energy reviews, n.12, v.5, p.1325-1344, 2008.

RODRIGUES, M.; WALTER, A.; FAAIJ, A. Co-firing of natural gas and biomass gas in biomass integrated gasification/combined cycle systems. Energy, v.28, n.11, p.1115-1131, 2003.

SAMANS, R.; BLANKE, J.; CORRIGAN, G.; DRZENIEK, M. The inclusive growth and development report 2015. Geneva: World Economic Forum, 2015.

SAWYER, D. 2015. Population and Sustainable Consumption in Brazil. Associaçao Brasileira de Estudos populacionais - abep. Rio de Janeiro: p.225-54, 2015.

SEEG. Contexto Do Brasil Na Emissão de Gases Efeito Estufa em 2015 . Sistema de Estimativas de Emissões e Remoções de Gases de Efeito Estufa. 2016. 
TOLMASQUIM, M. T., AMILCAR G.; GORINI, R. "Brazilian Energy Matrix - A Prospective (in Portuguese)." New Studies CEBRAP, n.79, 2007.

TURKENBURG, W. C.; FAAIJ, A. (2000). Renewable energy technologies (pp. 219-72). UNDP/UNDESA/WEC: Energy and the Challenge of Sustainability. World Energy Assessment. v.219-272, 2000.

UN. World Urban Population Infographics. United Nations report. 2014.

VIEIRA, F. V., \& VERÍSSIMO, M. P. Crescimento econômico em economias emergentes selecionadas: Brasil, Rússia, Índia, China (BRIC) e África do Sul. Economia e sociedade, v.18, n.3, p. 513-546, 2009.

VIOLA, E., \& FRANCHINI, M. 2017. Brazil and Climate Change: Beyond the Amazon. B. Routledge. New York: 2017.

WALTER, A.; DOLZAN, P.; QUILODRÁN, O.; OLIVEIRA, J. G.; SILVA, C.; PIACENTE, F.; SEGERSTEDT, A. Sustainability assessment of bio-ethanol production in Brazil considering land use change, GHG emissions and socioeconomic aspects. Energy Policy, v.39, n.10, p.5703-5716, 2011.

WELFLE, A. Balancing growing global bioenergy resource demands-Brazil's biomass potential and the availability of resource for trade. Biomass and Bioenergy, v.105, p.83-95, 2017.

WORLSDOMETERS. World Population by country. 2018. Available in $<$ http://www.worldometers.info/worldpopulation/>. Accessed in dezember 2018.

YANG, H.; YAN, R.; CHEN, H.; LEE, D. H.; ZHENG, C. Characteristics of hemicellulose, cellulose and lignin pyrolysis. Fuel, v.86, n.12-13, p .1781-1788, 2007. 